\title{
Anti-tumor activity of plant extracts against human breast cancer cells are different in monolayer and three-dimensional cell culture screening models: A comparison on 34 extracts
}

\author{
Nhan Lu-Chinh Phan ${ }^{1,2}$, Khuong Duy Pham 2,3 , Mai Thi-Thanh Nguyen ${ }^{2,4}$, Ngoc Phan Kim 2,3, \\ Kiet Dinh Truong ${ }^{5}$, Phuc Van Pham ${ }^{1,2,3,6, * 10}$
}

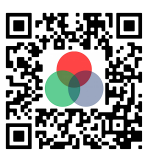

Use your smartphone to scan this QR code and download this article

${ }^{1}$ Stem Cell Institute, University of Science, Ho Chi Minh City, Viet Nam

${ }^{2}$ Viet Nam National University Ho Chi Minh City, Viet Nam

${ }^{3}$ Laboratory of Stem Cell Research and Application, University of Science, Ho Chi Minh City, Viet Nam

${ }^{4}$ Faculty of Chemistry, University of Science, Ho Chi Minh City, Viet Nam

${ }^{5}$ Medical Genetics Institute, Ho Chi Minh City, Viet Nam

${ }^{6}$ Cancer Research Laboratory, University of Science, Ho Chi Minh City, Viet Nam

\section{Correspondence}

Phuc Van Pham, Stem Cell Institute University of Science, Ho Chi Minh City, Viet Nam

Viet Nam National University Ho Chi Minh City, Viet Nam

Laboratory of Stem Cell Research and Application, University of Science, Ho Chi Minh City, Viet Nam

Cancer Research Laboratory, University of Science, Ho Chi Minh City, Viet Nam

Email: pvphuc@hcmuns.edu.vn; phucpham@sci.edu.vn

History

- Received: 2019-11-25

- Accepted: 2020-02-22

- Published: 2020-03-22

DOI : 10.15419/bmrat.v7i3.593

\section{Check for updates}

\section{Copyright}

(c) Biomedpress. This is an openaccess article distributed under the terms of the Creative Commons Attribution 4.0 International license.

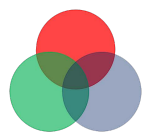

\begin{abstract}
Introduction: The monolayer cell culture model is a popular model for screening anti-tumor activity of plant extracts. However, almost the extracts selected for screening in this model have failed in subsequent animal models. Therefore, there is only about $5 \%$ of candidates from the original thousands of drugs that are screened which ultimately reach clinical trial. This study aimed to compare the differences in anti-tumor activity of 34 plant extracts against breast cancer cells in 2 models of monolayer cell culture (2D) and in three-dimensional (3D) cell culture. Methods: Four breast cancer cell lines (MCF-7, CD44+ CD24- MCF-7, VN9, and CD44+ CD24-VN9) were used to generate the 2D and 3D models (the 3D model was developed by culturing breast cancer cells in matrigel). The extracts were got from the plant extract library that prepared in the previous study. The anti-tumor activity was evaluated via half inhibitory concentrations( $I C_{50}$ values). Results: Of the 34 extracts, E12, E7, E5 and E6 of them had an effect on MCF-7, CD44 ${ }^{+}$CD24- MCF-7, VN9 and CD44 ${ }^{+}$CD24- VN9 cells, respectively. The results indicated 10 potentially strong candidates for future drug development targeting hypoxic areas in breast cancer. Conclusion: The 3D culture model exhibited higher resistance to extracts than the $2 \mathrm{D}$ culture model. The $\mathrm{CD} 44^{+} \mathrm{CD} 24^{-}$cell population of both VN9 and MCF-7 cell lines showed higher drug resistance than the original cell lines (VN9 and MCF-7).

Key words: breast cancer, drug screening, natural extract, CD44+CD24-
\end{abstract}

\section{INTRODUCTION}

For the discovery of new drugs, screening of natural compounds that target the proliferation of cancer cells is important ${ }^{1}$. For libraries with hundreds to thousands of extracts, they need to be screened with high-performance screening methods. Such methods allow the screening of many compounds at different concentrations at the same time on each target cell or the combination of compounds- with uniformity and high accuracy ${ }^{2,3}$.

Screening of extracts on cancer cell models in 2dimensional (2D) monolayer culture is limited because the monolayer model lacks the tumor cell characteristics of physiological tumors in the body ${ }^{4}$. Meanwhile, screening done on a cancer model in 3dimensional (3D) culture may be better for studying drug effects since the $3 \mathrm{D}$ culture model is more similar to the in vivo animal models (and possibly clinical trials); the 3D model more closely reflects characteristics of in vivo tumors, such as differentiation, tumor microenvironment, and distribution of hypoxia in certain populations ${ }^{5-7}$. Many methods have been developed to create 3D cells like tumors in the body; these methods include use of U-shaped bottom well , the hanging drop, and cell growth in bio-matrix ${ }^{6,8}$.

The method of using a U-shaped bottom well is heavily used in $3 \mathrm{D}$ cell model studies. However, one downside is that not all cell types can develop into 3D cell mass by this method ${ }^{9}$. For hanging drop culture, the advantage is that gravity is used to precipitate the cells together and thereby stimulate the cells to stick together into $3 \mathrm{D}$ spheres ${ }^{10}$. This method has a disadvantage of using very gentle manipulations and is difficult to develop if screened at high throughput automation. Meanwhile, the method of using biological substrates (like Matrigel) offers great potential for the development of $3 \mathrm{D}$ cell model ${ }^{11-13}$. Matrigel is usually stored in frozen form, at a concentration of 10 $15 \mathrm{mg} / \mathrm{mL}$; it is thawed at $4{ }^{\circ} \mathrm{C}$ and gelated in a temperature range of $24-37^{\circ} \mathrm{C}$ for 30 minutes. Matrigel promotes the differentiation of different cell lines (e.g. prostate, salivary gland, mammary epithelium, pancreas, Schwann cells, intestinal cells, and bone cells), of primary cell lines (e.g. sertoli cells, blood cells, cartilage cells, epithelial cells, endometrial cells, and fallopian epithelial cells), and even tissue explants (e.g.

Cite this article : Lu-Chinh Phan N, Duy Pham K, Thi-Thanh Nguyen M, Phan Kim N, Dinh Truong K, Van Pham P. Anti-tumor activity of plant extracts against human breast cancer cells are different in monolayer and three-dimensional cell culture screening models: A comparison on 34 extracts. Biomed. Res. Ther.; 7(3):3667-3677. 
neural crest, immature follicles, and zygote) ${ }^{14}$.

This study used matrigel to create a 3D cell model of breast cancer for the purpose of screening natural compounds that inhibit the growth of breast cancer cell . Modeling of 2D and 3D monolayer cancer cells was carried out in parallel (simultaneously) with the same evaluation agents, including Alarma Blue. The $\mathrm{IC}_{50}$ (half maximal inhibitory concentration) values were compared between $2 \mathrm{D}$ and 3D cancer cell models to evaluate and select the extract which showed different effects in these two models.

This study used 34 natural plant extracts and two control drugs (Doxorubicin and Tiparazamine) on 4 cell lines (MCF-7, CD44 ${ }^{+} \mathrm{CD} 24^{-} \mathrm{MCF}-7, \mathrm{VN} 9$, and CD $44^{+}$CD $24^{-}$VN9 cells).

\section{METHODS}

\section{Cell lines}

MCF-7 cell line was obtained from ATCC (Manassas, VA). VN9 cell line was obtained from the Stem Cell Institute, University of Science, VNU-HCM. MCF-7 and VN9 cells were cultured in DMEM/F12 (SigmaAldrich, St Louis, MO), 10\% fetal bovine serum (FBS) (Sigma-Aldrich, St. Louis, MO), 1\% antibioticantimycotic (Sigma-Aldrich, St Louis, MO). The $\mathrm{CD} 44^{+} \mathrm{CD} 24^{-}$cells were sorted from VN9 cells (and termed $\mathrm{CD} 44^{+} \mathrm{CD} 24^{-} \mathrm{VN} 9$ ) or from MCF-7 (and termed $\mathrm{CD} 44^{+} \mathrm{CD} 24^{-} \mathrm{MCF}-7$ ) by magneticactivated cell sorting (MACS; Miltenyi Biotec, Bergisch Gladbach, Germany), and then expanded in M171 medium (Thermo Fisher Scientific, Waltham, MA) with MEGS Suplement (Thermo Fisher Scientific, Waltham, MA) for maintenance of stemness. The $\mathrm{CD} 44^{+} \mathrm{CD} 24^{-}$populations corresponded to the cancer stem cell (CSC) populations.

\section{Chemicals}

In the research study, the library of the 34 extract (Table 1 ), which were coded with 'E' as the initial label (i.e. E1-E34), were obtained from the Division of Medicinal Chemistry, Faculty of Chemistry, University of Science, Vietnam National University Ho Chi Minh City, Vietnam. Doxorubicin hydrochloride and tirapazamine were purchased from Sigma-Aldrich.

\section{Cell culture in monolayer (2D) and three- dimensional (3D ) culture}

For 2D models, single cells (MCF-7, CD $44^{+} \mathrm{CD} 24^{-} \mathrm{MCF}-7$, VN9 or CD $44^{+} \mathrm{CD} 24^{-} \mathrm{VN}-$ 9) were harvested and seeded in 96-well plates at a final density of 1000 cells per well, and grown for 5 days. Fresh medium was replenished every two days. Cancer cells were cultured in DMEM/F12, 10\% FBS (Sigma-Aldirch), and 1\% antibiotic-antimycotic (Sigma-Aldrich). $\mathrm{CD} 44^{+} \mathrm{CD} 24^{-}$cancer cells were cultured in M171 medium (Thermo Fisher Scientific ) with MEGS supplement (Thermo Fisher Scientific). For the 3D model, $5 \mu \mathrm{L}$ of 1000 single cells was mixed with $5 \mu \mathrm{L}$ of matrigel (Sigma-Aldrich) on ice and placed on the edge of the well. The plate was incubated at $37^{\circ} \mathrm{C}$ in 10 minutes for gel polymerization, and then $100 \mu \mathrm{L}$ of pre-warmed medium was added on top of the gel. The pre-warmed medium was a requisite for manipulation of 3D culture to avoid melting the gel (Figure 1 ).

\section{Cell viability assay and IC $C_{50}$ determination}

After 5 days of culture, the cells and organoids were treated for 48 hours with the respective 34 extracts at the following concentrations: $31.25 \mu \mathrm{g} / \mathrm{ml}, 62.5$ $\mu \mathrm{g} / \mathrm{ml}, 125 \mu \mathrm{g} / \mathrm{ml}, 250 \mu \mathrm{g} / \mathrm{ml}, 500 \mu \mathrm{g} / \mathrm{ml}$, or 1000 $\mu \mathrm{g} / \mathrm{ml}$. The concentrations of doxorubicin evaluated were: $62.5 \mathrm{nM}, 125 \mathrm{nM}, 250 \mathrm{nM}, 500 \mathrm{nM}$, and $2000 \mathrm{nM}$; the concentrations of tirapazamine evaluated were: $15.625 \mu \mathrm{M}, 31.25 \mu \mathrm{M}, 62.5 \mu \mathrm{M}, 125 \mu \mathrm{M}$, $250 \mu \mathrm{M}$, and $500 \mu \mathrm{M}$. Then, Alarma Blue (SigmaAldrich) was added to the wells at a final concentration of $10 \mu \mathrm{g} / \mathrm{mL}$ and incubated in the dark for 1 hour. The fluorescence intensity was read using an DTX880 system (Beckman Coulter, Brea, CA) at excitation wavelength of $535 \mathrm{~nm}$, emission wavelength of $595 \mathrm{~nm}$, and integration time of $500 \mu \mathrm{s}$. The data were normalized to control values (untreated wells) and $\mathrm{IC}_{50}$ values were calculated with GraphPad Prism 7 (GraphPad Software, Inc., La Jolla, CA).

\section{Statistical analysis}

All experiments were performed in triplicate. Statistical significance was set at $P<0.05$. Data were analyzed by GraphPad Prism 7.

\section{RESULTS}

\section{$I_{50}$ values of extracts are different on MCF- $72 \mathrm{D}$ and 3D models}

The $\mathrm{IC}_{50}$ results of doxorubicin and tirapazamine showed that both 2D and 3D models were successfully established for anti-tumor activity evaluation (Table 2). The $\mathrm{IC}_{50}$ results of the 34 plant extracts on MCF-7 breast cancer cells in 2D and 3D models are summarized in Table 3.

There were 12/34 extracts which showed effects on both $2 \mathrm{D}$ and $3 \mathrm{D}$ culture models. These 12 extracts were: E4, E10, E11, E12, E17, E18, E20, E21, E22, E27, 
Table 1: List of 34 natural extracts used in this study

\begin{tabular}{|c|c|c|c|}
\hline Code of extract & Plant (solvent) & Code of extract & Plant (solvent) \\
\hline $\mathrm{E} 4$ & Buchanania Latifolia - $\left(\mathrm{CH}_{3} \mathrm{OH}\right)$ & E26 & Anisoptera costata $-\left(\mathrm{CH}_{3} \mathrm{OH}\right)$ \\
\hline E7 & M. Camptosperma - $\left(\mathrm{CH}_{3} \mathrm{OH}\right)$ & E27 & Anisoptera costata $-\left(\mathrm{CH}_{3} \mathrm{OH}\right)$ \\
\hline E8 & D. Dyeri - $\left(\mathrm{CH}_{3} \mathrm{OH}\right)$ & E28 & $\begin{array}{l}\text { Willughbeia cochinchinensis } \\
\left(\mathrm{CH}_{3} \mathrm{OH}\right)\end{array}$ \\
\hline E9 & H. recopei $-\left(\mathrm{CH}_{3} \mathrm{OH}\right)$ & E30 & Streblus ilicifolius $-\left(\mathrm{CH}_{3} \mathrm{OH}\right)$ \\
\hline E10 & H. recopei $-\left(\mathrm{CH}_{3} \mathrm{OH}\right)$ & E31 & B. pandurate $-\left(\mathrm{CH}_{3} \mathrm{OH}\right)$ \\
\hline E11 & S. thorelii- $\left(\mathrm{CH}_{3} \mathrm{OH}\right)$ & E32 & Paramignya trimera $-\left(\mathrm{CH}_{3} \mathrm{OH}\right)$ \\
\hline E12 & S. thorelii $-\left(\mathrm{CH}_{3} \mathrm{OH}\right)$ & E35 & Mangifera mekongiensis - $\left(\mathrm{CH}_{3} \mathrm{OH}\right)$ \\
\hline E13 & D. turbinatus - $\left(\mathrm{CH}_{3} \mathrm{OH}\right)$ & E36 & Embelia ribes $-\left(\mathrm{CH}_{3} \mathrm{OH}\right)$ \\
\hline E14 & D. turbinatus - $\left(\mathrm{CH}_{3} \mathrm{OH}\right)$ & E37 & $\begin{array}{l}\text { Willughbeia cochinchinensis } \\
\left(\mathrm{C}_{4} \mathrm{H}_{8} \mathrm{O}_{2}\right)\end{array}$ \\
\hline E15 & D. costatus $-\left(\mathrm{CH}_{3} \mathrm{OH}\right)$ & E38 & Artocarpus heterophyllus $-\left(\mathrm{C}_{4} \mathrm{H}_{8} \mathrm{O}_{2}\right)$ \\
\hline E16 & D. costatus $-\left(\mathrm{CH}_{3} \mathrm{OH}\right)$ & E39 & Mangifera mekongiensis - $\left(\mathrm{C}_{4} \mathrm{H}_{8} \mathrm{O}_{2}\right)$ \\
\hline E17 & Hopea odorata $-\left(\mathrm{CH}_{3} \mathrm{OH}\right)$ & $\mathrm{E} 40$ & Taxus wallichiana $-\left(\mathrm{CH}_{2} \mathrm{Cl}_{2}\right)$ \\
\hline E19 & Vatica odorata - $\left(\mathrm{CH}_{3} \mathrm{OH}\right)$ & E41 & Caesalpinia sappan - $\left(\mathrm{CH}_{2} \mathrm{Cl}_{2}\right)$ \\
\hline $\mathrm{E} 20$ & Vatica odorata $-\left(\mathrm{CH}_{3} \mathrm{OH}\right)$ & E42 & Trigona minor - (Hexan) \\
\hline E21 & Dipterocarpus alatus - $\left(\mathrm{CH}_{3} \mathrm{OH}\right)$ & E43 & B. pandurate - (Chloroform) \\
\hline E22 & Shorea roxburghii $-\left(\mathrm{CH}_{3} \mathrm{OH}\right)$ & E45 & Swintonia floribunda $-\left(\mathrm{CH}_{3} \mathrm{OH}\right)$ \\
\hline E25 & K. laurifolia $-\left(\mathrm{CH}_{3} \mathrm{OH}\right)$ & E46 & Mangifera reba Pierre $1897-\left(\mathrm{CH}_{3} \mathrm{OH}\right)$ \\
\hline
\end{tabular}

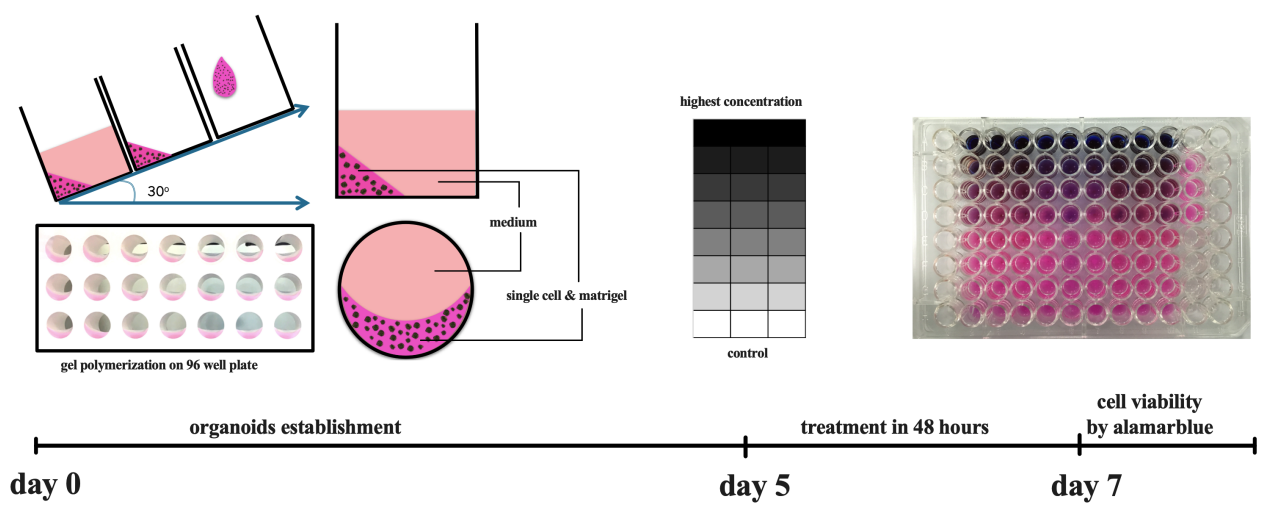

Figure 1: The 3D cell culture method using matrigel. The matrigel and the cells wered seed with density of 1000 cells/well. The matrigel was established on the edge of the well after $30 \mathrm{mins}$ in $37^{\circ} \mathrm{C}$ which has crescent shape. After 5 days in progress, the drug testing was process in 48 hours. 
Table 2: The $\mathrm{IC}_{50}$ of doxorubicin and tirapazamin on cell lines

\begin{tabular}{llll}
\hline Cell lines & Models & IC $_{50}$ DOX $(\mathbf{n g} / \mathbf{m L})$ & IC $_{50}$ TPZ $(\mu \mathbf{g} / \mathbf{m L})$ \\
\hline VN9 & 2D & 1476 & 292 \\
& 3D & 1868 & 128 \\
CD44 ${ }^{+}$CD24- VN9 & 2D & 98.52 & 315.2 \\
& 3D & 1711 & 105.4 \\
MCF-7 & 2D & 1674 & 159.4 \\
& 3D & 2354 & 68.14 \\
CD44 ${ }^{+}$CD24- MCF-7 & 2D & 278.3 & 174.9 \\
& 3D & 3131 & 147 \\
\hline
\end{tabular}

Abbreviations: DOX: doxorubicin, TPZ: tirapazamin, $\mathrm{IC}_{50}$ : half inhibitory concentration

Table 3: The IC 50 values of 34 extracts on MCF-7 breast cancer cell line

\begin{tabular}{|c|c|c|c|c|c|}
\hline \multirow[t]{2}{*}{ Extracts } & \multicolumn{2}{|c|}{ IC $_{50}$ values $(\mu \mathrm{g} / \mathrm{mL})$} & \multirow[t]{2}{*}{ Extracts } & \multicolumn{2}{|c|}{ IC $_{50}$ values $(\mu \mathrm{g} / \mathrm{mL})$} \\
\hline & 2D model & 3D model & & 2D model & 3D model \\
\hline $\mathrm{E} 4$ & 187.5 & 383.7 & E25 & 597.4 & 870.8 \\
\hline E7 & 248.2 & 332.8 & E27 & 165.3 & 242.5 \\
\hline E8 & 478.7 & 533.1 & E28 & 299.7 & 673.3 \\
\hline E9 & 701.4 & 653.5 & E30 & 1476 & 794 \\
\hline E10 & 310 & 154.7 & E31 & 257.3 & 308.5 \\
\hline E11 & 342.9 & 198.3 & E32 & 235.2 & 225.1 \\
\hline E12 & 303.5 & 160.4 & E35 & 4450 & 615.9 \\
\hline E13 & 1779 & 1061 & E36 & 2187 & 575.5 \\
\hline E14 & 348.6 & 593 & E37 & 326.1 & 308.8 \\
\hline E15 & 1106 & 639.8 & E38 & 368.1 & 692.2 \\
\hline E16 & 316.8 & 361.9 & E39 & 345.6 & 270.6 \\
\hline E17 & 159.4 & 232.4 & $\mathrm{E} 40$ & 70 & 1419 \\
\hline E18 & 112.4 & 230 & E41 & 526.2 & 2063 \\
\hline E19 & 489.5 & 621.8 & E42 & 499.7 & 359.6 \\
\hline E20 & 86.42 & 168.4 & $\mathrm{E} 43$ & 306 & 620.4 \\
\hline E21 & 57.67 & 71.97 & E45 & 155 & 361.9 \\
\hline E22 & 83.58 & 87.92 & E46 & 135.4 & 387.6 \\
\hline
\end{tabular}




\begin{tabular}{|c|c|c|c|c|c|}
\hline \multirow[t]{2}{*}{ Extracts } & \multicolumn{2}{|c|}{$\mathrm{IC}_{50}$ values $(\mu \mathrm{g} / \mathrm{mL})$} & \multirow[t]{2}{*}{ Extracts } & \multicolumn{2}{|c|}{$\mathrm{IC}_{50}$ values $(\mu \mathrm{g} / \mathrm{mL})$} \\
\hline & 2D model & 3D model & & 2D model & 3D model \\
\hline $\mathrm{E} 4$ & 66.2 & 360.3 & E25 & 173.6 & 587.8 \\
\hline E7 & 69.42 & 307.7 & E27 & 80.45 & 214.1 \\
\hline E8 & 103.2 & 937.8 & E28 & 134.9 & 481.6 \\
\hline E9 & 153 & 887.8 & E30 & 508.4 & 935.9 \\
\hline E10 & 50.48 & 162.2 & EE31 & 85.04 & 253.5 \\
\hline E11 & 58.14 & 217.5 & E32 & 56.65 & 223 \\
\hline E12 & 61.95 & 162 & E35 & 73.95 & 624.6 \\
\hline E13 & 262.4 & 1243 & E36 & 507 & 1215 \\
\hline E14 & 74.52 & 375.2 & E37 & 103.5 & 322.7 \\
\hline E15 & 258.3 & 699.7 & E38 & 229.8 & 980.4 \\
\hline E16 & 70.91 & 146.4 & E39 & 62.65 & 386.6 \\
\hline E17 & 20.31 & 56.97 & $\mathrm{E} 40$ & 274.5 & 1648 \\
\hline E18 & 145 & 39.89 & E41 & 303.3 & 1257 \\
\hline E19 & 31.88 & 227.4 & E42 & 102.3 & 293.9 \\
\hline E20 & 35.6 & 89.56 & E43 & 60.97 & 449.6 \\
\hline E21 & 26.71 & 252.9 & E45 & 32.16 & 295.5 \\
\hline E22 & 809.5 & 110.4 & E46 & 71.98 & 459.6 \\
\hline
\end{tabular}

Abbreviation: IC $_{50}$ : half inhibitory concentration

E45, and E46. However, most of the extracts predominantly had effects on the 2D model. In fact, 27 extracts on the $3 \mathrm{D}$ models were correlated with increased resistance by the cancer cells as compared to the resistance on the 2D models. Specifically, there were 7 extracts that had an $\mathrm{IC}_{50}$ values in the $3 \mathrm{D}$ model which were lower than in the $2 \mathrm{D}$ culture model. The $7 \mathrm{ex}-$ tracts were: E10, E12, E15, E30, E35, E36, and E42 (Figure 2 ). Thus, they are potential candidates for further use in the 3D culture model of MCF-7 breast cancer.

\section{The results of hit extracts on CD44 ${ }^{+}$CD24 $^{-}$MCF-7 in 2D and 3D models}

There were $7 / 34$ extracts that had effects on both $2 \mathrm{D}$ and 3D culture models. These 7 extracts were: E7, E10, E12, E17, E18, E19, E21, and E45. However, the majority of the extracts predominantly showed effects on the 2D model (Table 5 ). As seen in Table 5, cells grown in the $3 \mathrm{D}$ model showed more resistance to the effects of the 32 extracts than the cells grown in the 2D model. In particular, there were 2 extracts which had $\mathrm{IC}_{50}$ values in the $3 \mathrm{D}$ model that were lower than the values in the 2D model; those 2 extracts were E26 and E22 (Figure 3 ). Therefore, they are potential candidates for further research in the $3 \mathrm{D}$ culture model of the MCF-7 breast cancer stem cell (CSC). Comparing with the results on the MCF-7 cell line, it was observed that the $\mathrm{CD} 44^{+} \mathrm{CD} 24^{-}$sub-population of MCF-7 cells has a much higher resistance to the same extracts tested.

\section{The results of hit extracts on VN9 cultured in 2D and 3D models}

There were 5/34 extracts which showed effects on both $2 \mathrm{D}$ and $3 \mathrm{D}$ culture models. The 5 extracts were: E4, E7, E20, E21, and E45. However, most of the extracts had predominant effects on the 2D models (Table 6). As Table 6 demonstrates, 29 extracts on the 3D models were correlated with increased resistance by the cancer cells, as compared to their resistance on the $2 \mathrm{D}$ models. In particular, 5 extracts had $\mathrm{IC}_{50}$ values in the $3 \mathrm{D}$ model that were lower than the values in the 2D model. The 5 extracts were: E15, E18, E22, E25 and E30 (Figure 4). Therefore, these are potential 
Table 5: Summary of hit extracts on each cell types and models

\begin{tabular}{llll}
\hline Cells & 2D model & 3D model & $\begin{array}{l}\text { The extracts more } \\
\text { sensitive on 3D than 2D }\end{array}$ \\
\hline MCF-7 & E20, E21, E22, E40 & $\begin{array}{l}\text { E10, E12, E15, E30, E35, } \\
\text { E36, E42 }\end{array}$ \\
CD44 ${ }^{+}$CD24 ${ }^{-}$MCF-7 & E4, E7, E10, E11, E12, E14, E16, E17, E18, E20 & E26, E22 \\
& $\begin{array}{l}\text { E17, E19, E20, E21, E27, E31, } \\
\text { E32, E35, E39, E43, E45, E46 }\end{array}$ & \\
VN9 & $-\quad$ E15, E18, E22, E30 \\
CD44 ${ }^{+}$CD24 ${ }^{-}$VN9 & E4, E7, E10, E11, E12, E14, E16, E7, E21 & E18, E22 \\
& E17, E19, E20, E21, E31, E32, & \\
& E35, E39, E45 & \\
\hline
\end{tabular}

Table 6: The IC $\mathrm{I}_{50}$ values of 34 extracts on VN9 breast cancer cell line

\begin{tabular}{|c|c|c|c|c|c|}
\hline \multirow[t]{2}{*}{ Extracts } & \multicolumn{2}{|c|}{ IC $_{50}$ values $(\mu \mathrm{g} / \mathrm{mL})$} & \multirow[t]{2}{*}{ Extracts } & \multicolumn{2}{|c|}{$\mathrm{IC}_{50}$ values $(\mu \mathrm{g} / \mathrm{mL})$} \\
\hline & 2D model & 3D model & & 2D model & 3D model \\
\hline E4 & 238.9 & 518.2 & E25 & 4681 & 722.9 \\
\hline E7 & 345.6 & 297 & E27 & 497.8 & 345.1 \\
\hline E8 & 1287 & 588.2 & E28 & 1806 & 613.5 \\
\hline E9 & 916.8 & 535.7 & E30 & 4976 & 1568 \\
\hline E10 & 712.6 & 270.9 & E31 & 293.5 & 463.9 \\
\hline E11 & 559.2 & 686.4 & E32 & 403.6 & 347 \\
\hline E12 & 635.9 & 496.2 & E35 & 5799 & 3004 \\
\hline E13 & 7756 & 2706 & E36 & 7437 & 3605 \\
\hline E14 & 531.4 & 638.3 & E37 & 559.3 & 977.5 \\
\hline E15 & 5744 & 1088 & E38 & 3158 & 2260 \\
\hline E16 & 377.7 & 987.1 & E39 & 697.3 & 847.6 \\
\hline E17 & 211 & 431 & E40 & 267.2 & 1212 \\
\hline E18 & 2055 & 430.6 & E41 & 1083 & 871.1 \\
\hline E19 & 357.5 & 654 & E42 & 2136 & 963.8 \\
\hline E20 & 103.8 & 122.6 & E43 & 247.5 & 504.1 \\
\hline E21 & 304.2 & 146.1 & E45 & 196.1 & 262 \\
\hline E22 & 2964 & 324.1 & E46 & 1080 & 417.3 \\
\hline
\end{tabular}

Abbreviation: $\mathrm{IC}_{50}$ : half inhibitory concentration 


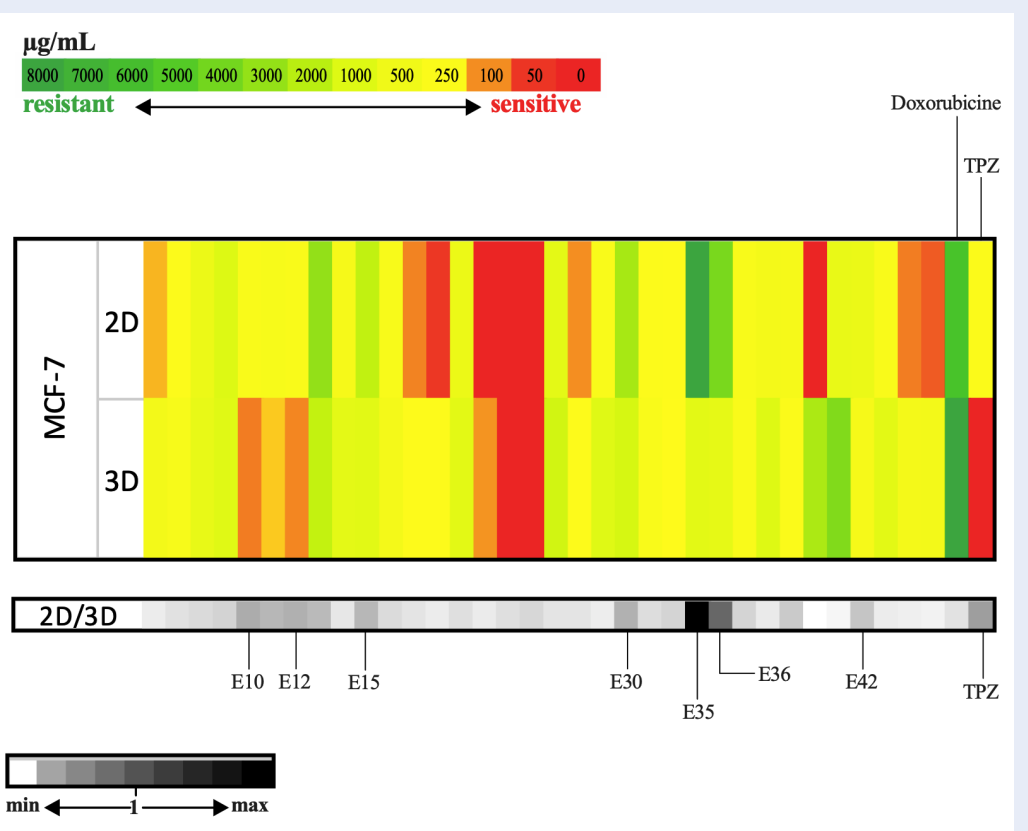

Figure 2: Comparing the IC $\mathrm{I}_{50}$ values of 34 extracts, doxorubicin and tirapazamine on MCF-7 breast cancer cell line. Scale 1: Red corresponds to sensitivity, green corresponds to high resistance. Scale 2: Black corresponds to, ratio of $2 \mathrm{D} / 3 \mathrm{D}$ concentration is greater than 1. Gray white corresponds to, ratio of $2 D / 3 D$ concentration is less than 1. Abbreviations: TPZ: tirapazamine, 2D: mononuclear cell culture, 3D: three-dimensional cell culture model, $\mathbf{I} \mathbf{C}_{50}$ : half inhibitory concentration

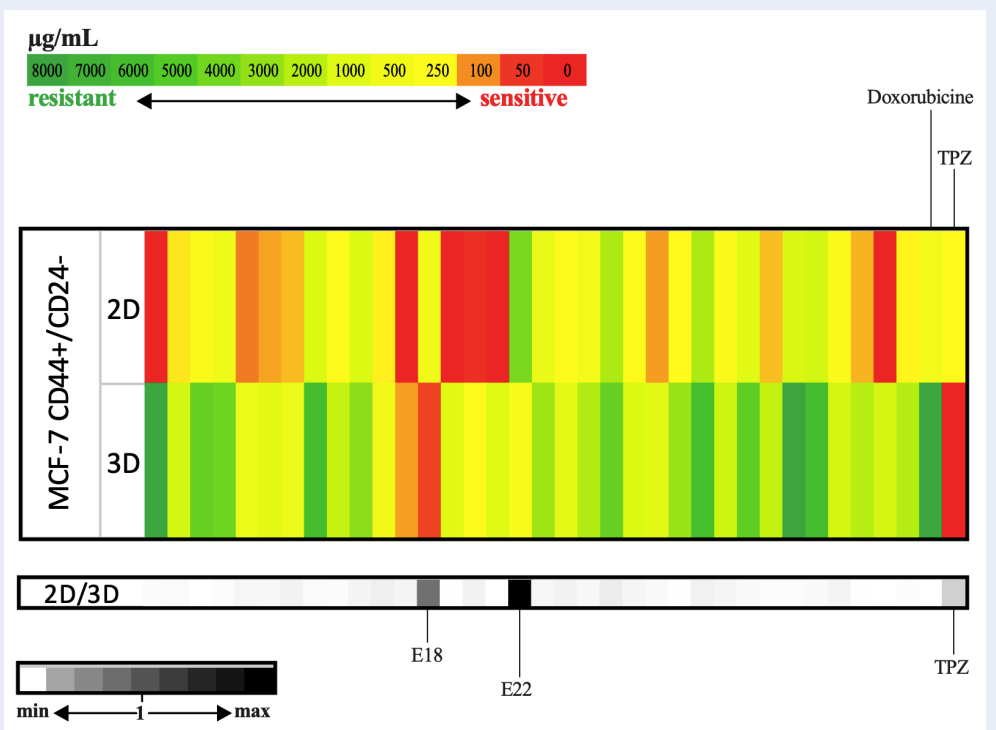

Figure 3: Comparing the IC $\mathrm{C}_{50}$ values of 34 extracts, Dox and TPZ on CD44 ${ }^{+}$CD24 ${ }^{-}$MCF-7 breast cancer cell line. Scale 1: Red corresponds to sensitivity, green corresponds to high resistance. Scale 2: Black corresponds to ratio of $2 D / 3 D$ concentration is greater than 1 . Gray white corresponds to ratio of $2 D / 3 D$ concentration is less than 1. Abbreviations: Dox: doxorubicin, TPZ: tirapazamine, 2D: mononuclear cell culture, 3D: three-dimensional cell culture model 


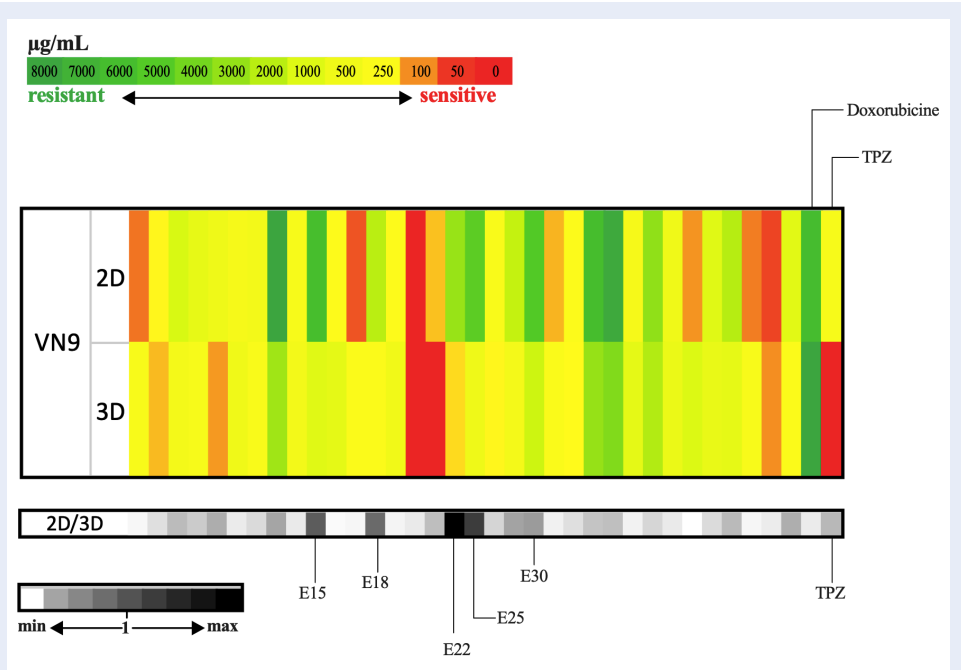

Figure 4: Comparing the IC $\mathrm{C}_{50}$ values of 34 extracts, Dox and TPZ on VN9 breast cancer cell line. Scale 1: Red corresponds to sensitivity, green corresponds to high resistance. Scale 2: Black corresponds to ratio of 2D/3D concentration is greater than 1 . Gray white corresponds to ratio of $2 \mathrm{D} / 3 \mathrm{D}$ concentration is less than 1 . Abbreviations: Dox: doxorubicin, TPZ: tirapazamine, 2D: mononuclear cell culture, 3D: three-dimensional cell culture model

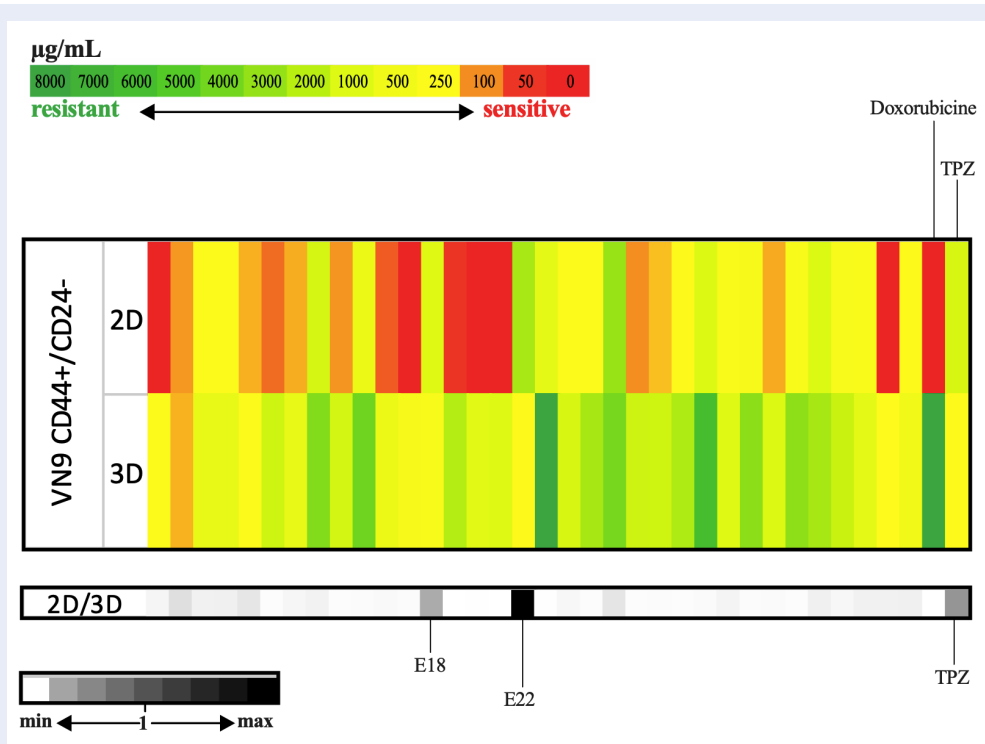

Figure 5: Comparing the $\mathrm{IC}_{50}$ values of 34 extracts, Dox and TPZ on CD44 ${ }^{+}$CD24 ${ }^{-}$VN9 breast cancer cell line. Scale 1: Red corresponds to sensitivity, green corresponds to high resistance. Scale 2: Black corresponds to ratio of $2 \mathrm{D} / 3 \mathrm{D}$ concentration is greater than 1 . Gray white corresponds to ratio of $2 \mathrm{D} / 3 \mathrm{D}$ concentration is less than 1. Abbreviations: Dox: doxorubicin, TPZ: tirapazamine, 2D: mononuclear cell culture, 3D: three-dimensional cell culture model 
candidates for further studies in the $3 \mathrm{D}$ culture model of VN9 breast cancer.

\section{Results of hit extracts on CD44 ${ }^{+}$CD24- VN9 cultured in 2D and 3D}

There were $6 / 34$ extracts affected both the $2 \mathrm{D}$ and $3 \mathrm{D}$ culture models: E4, E7, E10, E12, E18, and E45. Most of the extracts, however, mainly affected the 2D models (Table 7). As shown in Table 7, 32 extracts on the $3 \mathrm{D}$ models were correlated with increased resistance by the cancer cells, as compared to their resistance on the $2 \mathrm{D}$ models. In particular, there were 2 extracts which had $\mathrm{IC}_{50}$ values in the $3 \mathrm{D}$ model that were lower those in the $2 \mathrm{D}$ culture model; these extracts were E18 and E22 (Figure 5 ). Thus, they are potential candidates for further studies in the $3 \mathrm{D}$ VN9 breast CSC model. Comparison of screening results of VN9 with $\mathrm{CD} 44^{+} \mathrm{CD} 24^{-}$phenotype versus the original VN9 demonstrated that the CSC cell line (CD $44^{+} \mathrm{CD} 24^{-}$VN9) was more resistant to the extracts in the $3 \mathrm{D}$ culture model. Therefore, in this study, the number of extracts tested that showed an effect on this cell line was 2, indicating that VN9 CSC can carry more resistant characteristics than normal cells.

\section{DISCUSSION}

The use of bio-matrix substrates (such as matrigel) to create $3 \mathrm{D}$ culture models is very convenient for drug screening. Use of a gel forming method- that contains the cells on the side of the culture well in a 96-well plate- facilitates easy manipulation without disrupting the gel structure or limiting cell growth in the form of single layer in the center of the well. This method also allows the creation of a 3D cell mass with a size of $100 \mu \mathrm{m}$ within 5 days of culture. The drug test is conducted in 48 hours such that the entire drug testing procedure can be summarized in 7 days. In order to minimize errors when comparing $2 \mathrm{D}$ and $3 \mathrm{D}$ models, we conducted all experiments with both models in parallel. For both 2D and 3D models, the threshold of extracting effect was lower than $200 \mu \mathrm{g} / \mathrm{mL}$.

A number of published studies have show that $3 \mathrm{D}$ breast cell culture better reflect the histological, biological, and molecular features of primary tumors than the same cells cultured using traditional 2D techniques ${ }^{15}$. In a study by Imamura et al., on a 3D breast cancer model, the breast cell mass was found to have the presence of a hypoxic cell population ${ }^{7}$; it is for this reason that the cell mass becomes sensitive to tiparazamine. In our study, we show that 10 extracts have the same effect as tiparazamine on breast cancer cells, and that they might be suitable candidates for hypoxia-targeted drug development (Table 5). Furthermore, in their study, Imamura and colleagues also showed that expression of $\mathrm{Ki}-67$ was less in $3 \mathrm{D}$ breast cancer cell mass than in $2 \mathrm{D}$, suggesting that the greater G0-dormant subpopulation was responsible for drug resistance in 3D culture.

Many studies have show that the breast cancer cell population with phenotype $\mathrm{CD} 44^{+} \mathrm{CD} 24^{-}$possesses higher tolerability to chemotherapy, hormone therapy, and radiotherapy ${ }^{16-21}$. Thus, for the drug screening in our study, these 4 breast cancer cell lines were suitable for our evaluations: MCF-7, CD $44^{+} \mathrm{CD} 24^{-} \mathrm{MCF}-7, \mathrm{VN} 9, \mathrm{CD} 44^{+} \mathrm{CD} 24^{-} \mathrm{VN} 9$. Morever, a promising outcome from out study is the identification of 10 extracts which have a more sensitive effect on the $3 \mathrm{D}$ culture model than the $2 \mathrm{D}$ culture model. These 10 extracts include: E10, E12, E15, E18, E22, E26, E30, E35, E36, and E42. These could be suitable candidates for the next steps towards developing drugs that target the hypoxic region in breast cancer. Therapies targeting cancer cells in areas of hypoxia and studies to discern mechanisms have garnered increase interest for cancer treatment. Hypoxia-related mechanisms such as overexpression of hypoxia-inducible factor (HIF) are also important avenues of research. Inhibiting HIF activity and changing the molecules involved in HIF offer hope for identifying molecular target to inhibit tumor growth or even completely halt growth ${ }^{22}$. HIF-1 also induces an increase in adenosine $2 \mathrm{~B}$ receptor expression, thereby promoting the enrichment of breast cancer stem cells by activating protein kinase C- $\delta^{23}$.

Therefore, in the study herein, it was shown that the use of a 3D model of breast cancer cell culture for drug screening reflects a huge difference in drug resistance and drug sensitivity when compared to the $2 \mathrm{D}$ culture model. The matrigel 3D culture model is significant for screening compounds related to hypoxiabased therapy for breast cancer.

\section{CONCLUSION}

Medium-throughput screening on breast cancer cell models MCF-7, CD $44^{+} \mathrm{CD} 24^{-}$MCF-7, VN9, and $\mathrm{CD} 44^{+} \mathrm{CD} 24^{-} \mathrm{VN} 9$, in $2 \mathrm{D}$ and $3 \mathrm{D}$ culture, with 34 extracts showed that resistance to these extracts occurred when cancer cells were cultured in 3D. Resistance to extracts also manifested in the $\mathrm{CD} 44^{+} \mathrm{CD} 24^{-}$cell populations (i.e. CSC populations). There were $12 / 34$ and $7 / 34$ extracts which affected MCF-7 and CD44 ${ }^{+} \mathrm{CD} 24^{-}$MCF-7 cells, respectively. For the Vietnamese breast cancer cell line 


\begin{tabular}{|c|c|c|c|c|c|}
\hline \multirow[t]{2}{*}{ Extracts } & \multicolumn{2}{|c|}{$\mathrm{IC}_{50}$ values $(\mu \mathrm{g} / \mathrm{mL})$} & \multirow[t]{2}{*}{ Extracts } & \multicolumn{2}{|c|}{$\mathrm{IC}_{50}$ values $(\mu \mathrm{g} / \mathrm{mL})$} \\
\hline & 2D model & 3D model & & 2D model & 3D model \\
\hline $\mathrm{E} 4$ & 38.15 & 116.8 & E25 & 292.7 & 2456 \\
\hline E7 & 69.24 & 74.54 & E27 & 114.4 & 402.6 \\
\hline E8 & 112.8 & 255.3 & E28 & 108.6 & 793.3 \\
\hline E9 & 118 & 249.6 & E30 & 915.5 & 1218 \\
\hline E10 & 74.13 & 104 & E31 & 67.14 & 480.1 \\
\hline E11 & 59.78 & 475 & E32 & 76.9 & 479.4 \\
\hline E12 & 73.57 & 252.2 & E35 & 99.37 & 738.9 \\
\hline E13 & 426.4 & 1107 & E36 & 364.7 & 1855 \\
\hline E14 & 68.61 & 442.8 & E37 & 119.1 & 333.4 \\
\hline E15 & 236 & 1296 & E38 & 160.5 & 1022 \\
\hline E16 & 56.12 & 229.6 & E39 & 73.18 & 362.4 \\
\hline E17 & 27.7 & 162.5 & $\mathrm{E} 40$ & 137.5 & 992.6 \\
\hline E18 & 340.2 & 144.8 & E41 & 372.8 & 790.6 \\
\hline E19 & 47.05 & 685.8 & E42 & 146.6 & 515 \\
\hline E20 & 38.34 & 315.4 & E43 & 126.1 & 301.5 \\
\hline E21 & 30.58 & 342.5 & E45 & 39.07 & 90.3 \\
\hline E22 & 777.9 & 92.74 & E46 & 90.46 & 193 \\
\hline
\end{tabular}

Abbreviation: IC $_{50}$ : half inhibitory concentration

(VN9), there were 5/34 and 6/34 extracts which affected the VN9 and CD $44^{+} \mathrm{CD} 24^{-}$VN9 cells, respectively. Overall, our study results indicated 10 potential candidates for future drug development targeting hypoxia in breast cancer.

\section{ABBREVIATIONS}

Dox: Doxorubicin

HIF: Hypoxia-Inducible Factor

TPZ: Tirapazamine

VN9: Vietnamse breast cancer cell line \#9

\section{CONFLICT OF INTEREST}

The authors declare that there is no conflict of interests regarding the publication of this article.

\section{AUTHOR CONTRIBUTIONS}

Nhan Phan designed the project and carried out the experiments. Khuong Pham contributed to feasibility experiments. Mai Nguyen provided the extract. Nhan Phan analyzed the data and wrote the paper with contributions from all authors. Phuc Pham, Kiet Truong and Ngoc Phan suggested the idea, corrected the scientific matters, english wording and review all paper.

\section{ACKNOWLEDGMENTS}

This work was supported by the Vietnam National University, Ho Chi Minh City, Vietnam, under grant number A2015-18-01.

\section{REFERENCES}

1. Futamura $\mathrm{Y}$, Yamamoto $\mathrm{K}$, Osada H. Phenotypic screening meets natural products in drug discovery. Biosci Biotechnol Biochem. 2017;81(1):28-31. PMID: 27885937. Available from: https://doi.org/10.1080/09168451.2016.1248365.

2. Alexandrov V, Brunner D, Hanania T, Leahy E. Highthroughput analysis of behavior for drug discovery. Eur $\mathrm{J}$ Pharmacol. 2015;750(89):82. PMID: 25592319. Available from: https://doi.org/10.1016/j.ejphar.2014.11.047.

3. Mullard A. Microfluidics platform lowers barrier to drug combination screening. Nat Rev Drug Discov. 2018;17(10):691692. PMID: 30270346 . Available from: https://doi.org/10.1038/ nrd.2018.161.

4. Verjans ET, Doijen J, Luyten W, Landuyt B, Schoofs L. Threedimensional cell culture models for anticancer drug screening: Worth the effort? . J Cell Physiol. 2018;233(4):2993-3003. PMID: 28618001. Available from: https://doi.org/10.1002/jcp. 26052.

5. Haycock JW. 3D cell culture: a review of current approaches and techniques. Methods Mol Biol. 2011;2011(695):1-15. 
PMID: 21042962. Available from: https://doi.org/10.1007/9781-60761-984-0_1.

6. Breslin S, O'Driscoll L. Three-dimensional cell culture: the missing link in drug discovery. Drug Discov Today. 2013;18(56):240-249. PMID: 23073387. Available from: https://doi.org/ 10.1016/j.drudis.2012.10.003.

7. Imamura $Y$, Mukohara $Y$, Shimono $T$, Funakoshi $Y$, Chayahara $\mathrm{Y}$, Toyoda N, et al. Comparison of 2D- and 3D-culture models as drug-testing platforms in breast cancer. Oncol Rep. 2015;33(4):1837-1843. PMID: 25634491. Available from: https://doi.org/10.3892/or.2015.3767.

8. Abe-Fukasawa N, Otsuka K, Aihara A, Itasaki N, Nishino T. Novel 3D Liquid Cell Culture Method for Anchorageindependent Cell Growth, Cell Imaging and Automated Drug Screening. Sci Rep. 2018;8(1):3627. PMID: 29483620. Available from: https://doi.org/10.1038/s41598-018-21950-5.

9. Mittler F, Obeïd P, Rulina AV, Haguet V, Gidrol X, Balakirev MY. High-Content Monitoring of Drug Effects in a 3D Spheroid Model. Front Oncol. 2017;(7):293. PMID: 29322028. Available from: https://doi.org/10.3389/fonc.2017.00293.

10. Eder T, Eder IE. 3D Hanging Drop Culture to Establish Prostate Cancer Organoids. Methods Mol Biol. 2017;(1612):167-175. PMID: 28634942. Available from: https://doi.org/10.1007/9781-4939-7021-6_12.

11. Nguyen-Ngoc KV, Shamir ER, Huebner RJ, Beck JN, Cheung KJ, Ewald AJ. 3D culture assays of murine mammary branching morphogenesis and epithelial invasion. Methods Mol Biol. 2015;p. 135-162. PMID: 25245692. Available from: https: //doi.org/10.1007/978-1-4939-1164-6_10.

12. Shin $\mathrm{HS}$, Hong $\mathrm{HJ}$, Koh WG, Lim JY. Organotypic 3D Culture in Nanoscaffold Microwells Supports Salivary Gland Stem-CellBased Organization. ACS Biomater Sci Eng. 2018;4(12):43114320. PMID: 30591951. Available from: https://doi.org/10. 1021/acsbiomaterials.8b00894.

13. Dolega ME, Abeille F, Picollet-D'hahan N, Gidrol X. Controlled $3 \mathrm{D}$ culture in Matrigel microbeads to analyze clonal acinar development. Biomaterials. 2015;p. 347-357. PMID: 25818441. Available from: https://doi.org/10.1016/j.biomaterials.2015.02. 042.

14. Kleinman HK, Martin GR. Matrigel: basement membrane matrix with biological activity. Seminars in cancer biology. 2005;15(5):378-386. PMID: 15975825. Available from: https: //doi.org/10.1016/j.semcancer.2005.05.004.

15. Lee JM, Mhawech-Fauceglia P, Lee N, Parsanian LC, Lin YG, Gayther SA, et al. A three-dimensional microenvironment alters protein expression and chemosensitivity of epithelial ovarian cancer cells in vitro. Lab Invest. 2013;93(5):528 42. PMID: 23459371. Available from: https://doi.org/10.1038/ labinvest.2013.41.

16. Palomeras S, Ruiz-Martínez S, Puig T. Targeting Breast Cancer Stem Cells to Overcome Treatment Resistance. Molecules. 2018;23(9). PMID: 30200262. Available from: https://doi.org/ 10.3390/molecules23092193.

17. Sun H, Jia J, Wang X, Ma B, Di L, Song G, et al. CD44+/CD24breast cancer cells isolated from MCF-7 cultures exhibit enhanced angiogenic properties. Clin Transl Oncol. 2013;15(1). PMID: 22855175. Available from: https://doi.org/10.1007/ s12094-012-0891-2.

18. Deng X, Apple S, Zhao H, Song J, Lee M, Luo W, et al. CD24 Expression and differential resistance to chemotherapy in triplenegative breast cancer. Oncotarget. 2017;8(24):38294-38308. PMID: 28418843. Available from: https://doi.org/10.18632/ oncotarget.16203.

19. Rodríguez $C E$, Berardi $D E$, Abrigo $M$, Todaro $L B$, de Kier Joffé $E D B$, Fiszman GL. Breast cancer stem cells are involved in Trastuzumab resistance through the HER2 modulation in 3D culture. J Cell Biochem. 2018;119(2):1381-1391. PMID: 28722778. Available from: https://doi.org/10.1002/jcb.26298.

20. Chekhun VF, Lukianova NY, Chekhun SV, Bezdieniezhnykh NO, Zadvorniy TV, Borikun TV, et al. Association of CD44(+)CD24(-/low) with markers of aggressiveness and plasticity of cell lines and tumors of patients with breast cancer. Exp Oncol. 2017;39(3):203-211. Available from: https://doi. org/10.31768/2312-8852.2017.39(3):203-211.

21. Uchiumi K, Tsuboi K, Sato N, Ito T, Hirakawa H, Niwa T, et al. Cancer stem-like properties of hormonal therapy-resistant breast cancer cells. Breast Cancer. 2019;26(4):459-470. PMID 30610551. Available from: https://doi.org/10.1007/s12282018-00944-1.

22. Badowska-Kozakiewicz AM, Budzik MP, Przybylski J. Hypoxia in breast cancer. Pol J Pathol. 2015;66(4):337-346. PMID: 27003764. Available from: https://doi.org/10.5114/pjp.2015. 57245.

23. Lan J, Lu H, Samanta D, Salman S, Lu Y, Semenza GL. Hypoxiainducible factor 1-dependent expression of adenosine receptor $2 \mathrm{~B}$ promotes breast cancer stem cell enrichment. Proc Natl Acad Sci U S A;115(41):E9640-e9648. PMID: 30242135. Available from: https://doi.org/10.1073/pnas.1809695115. 